\title{
3つのレベルの内発的動機づけを高める: 動機 づけを高める方略の効果検証
}

\section{Enhancing Intrinsic Motivation at Three Levels: The Effects of Motivational Strategies}

\section{田中博晃 (たなかひろあき) 広島国際大学}

Traditionally, motivation researchers have been more concerned about what motivation is rather than how to motivate students. Recently, research interests have shifted towards educational purposes and an increasing number of studies now propose motivational strategies. Motivational strategies refer to "methods and techniques to generate and maintain the learners' motivation" (Dörnyei, 2001, p. 2). Using motivational strategies is generally believed to facilitate students' motivation, but only a few studies have found empirical evidence to support this claim. For example, Hiromori (2006) used "creative writing activities with student self-monitoring techniques" as a motivational strategy and showed that the strategy had a significant positive effect on students' motivation toward learning English. Tanaka and Hiromori (2007) proposed that "group presentation activities" are a useful motivational strategy. They successfully enhanced students' intrinsic motivation during a 5-week intervention. However, the number of studies that examine the effect of motivational strategies in the actual English language classroom is limited. In this article, I would like to point out two drawbacks of the above studies.

The first drawback is related to the definition of motivation. Most of the preceding studies on motivation define motivation as a trait attribute. However, many researchers segmentalize motivation into different levels (e.g., Crookes \& Schmidt, 1991). Vallerand and Ratelle (2002) analyzed intrinsic motivation at three levels,

JALT Journal, Vol. 31, No. 2, November 2009 
namely the situational level, contextual level, and global level. They recommend that motivation be considered not merely as a unitary concept, but as a complex concept. However, studies examining the effect of motivational strategies focus only on the trait and unitary aspects of motivation. Thus, there needs to be an examination of the effect of motivational strategies on motivation at different levels. In this article, three types of intrinsic motivation are addressed, namely intrinsic motivation for listening/ speaking activities, intrinsic classroom motivation, and intrinsic trait motivation.

The second drawback concerns research design. Much of the research that examines the effect of motivational strategies adopts a pre-post design. However, in order to capture motivational changes in more detail, additional measurement times would be useful. In this article, intrinsic motivation was measured at three different times: that is, pre-measurement, mid-measurement, and post-measurement.

Thus, this study aims to enhance students' intrinsic motivation at three levels. I adopt Self-Determination Theory (SDT), a well-developed motivation theory in psychology, as the theoretical underpinning. This theory provides a useful framework for examining the effect of motivational strategy because it assumes the existence of three psychological needs (i.e., the need for autonomy, competence, and relatedness) as prerequisites for enhancing student motivation.

The purposes of this study are as follows: (1) to enhance intrinsic motivation to engage in listening activities; (2) to enhance intrinsic motivation to engage in speaking activities; (3) to enhance intrinsic classroom motivation; and (4) to enhance intrinsic trait motivation. This study further explores facilitating factors of intrinsic motivation at the three levels. Thus, this article also aims (5) to examine which psychological need (the need for autonomy, competence or relatedness) plays the most significant role in students' motivational development; and (6) to explore new facilitating factors of intrinsic motivation.

Fifty-two university students who were enrolled in a 1st-year English language course participated in this study. The students met once a week in a 90-minute class. The intervention was given to them for 15 weeks. Prior to the beginning of the intervention, students were given questionnaires about language learning motivation and the three psychological needs. The same questionnaires were administered in the middle and at the end of the intervention. An open-ended questionnaire was also administered to students at the post-measurement stage.

The results of the quantitative analysis showed that: (1) the intervention had a significant positive effect on students' intrinsic motivation to engage in listening/ speaking activities and intrinsic classroom motivation; (2) the need for competence had a strong relationship with the development in students' intrinsic motivation to engage in listening activities; (3) the need for competence and relatedness had a strong relationship with development in students' intrinsic motivation to engage in speaking activities; (4) all three needs were related to the development in intrinsic classroom motivation. Further, the results of qualitative analysis indicated that (5) "usefulness" might be another facilitating factor of motivation. 


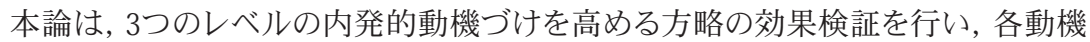
づけを高めた要因を探索することを目的とする。日本人大学生52名を対象に教育的 介入を行い, プレ測定, 中間測定, ポスト測定によって動機づけの変動を検討した。 その結果, (1) 教育的介入によって, 授業活動レベルの動機づけと英語授業への動 機づけが高まった，(2)リスニング活動への動機づけの上昇と関連が強かったのは, 有能性の欲求であった，(3) スピーキング活動への動機づけの上昇と関連が強かった のは, 有能性と関係性の欲求であった, (4) 英語授業への動機づけの上昇と関連が 強かったのは, 3欲求のすべてであった。また方略の効果を質的研究の観点からも検 証した結果，(5)授業活動レベルの動機づけの上昇と3欲求の関連性が裏付けられ た, (6)「実用性の付与」が内発的動機づけを高める新たな要因である可能性が示さ れた。

\section{はじめに}

学習者の動機づけをいかにして高めるかという問題は, 長らく動機づけ研究の課 題であった(例えば, Dörnyei, 2001; 三浦, 1983)。従来, この問題は動機づけの変化と それに対する社会的要因や環境的要因の関連として, そして近年では教育現場での 動機づけを高めるという教科教育指導の一環として注目されている。そのため動機づ けを高めるという教育学的視点を重視した研究が増え, 動機づけを高める方略の効 果を検証した研究が行われている。そこで本論は, 今までの動機づけを高める方略 の効果検証研究の問題点を 2 点指摘した上で, その問題点を克服する形で内発的動 機づけを高める方略の効果の検証を行う。

\section{背景}

\section{動機づけを高める研究}

英語教育学研究における動機づけ研究は, 動機づけの分類(例えば, Dörnyei, 1990; Kimura, Nakata, \& Okumura, 2001), 動機づけと学習成果, 学習方略, 不安など の諸要因との関連の分析(例えば, Ehrman \& Oxford, 1989), 動機づけの発達(例え ば, Gardner, Masgoret, Tennant, \& Mihic, 2004)といった多様な形で行われてきた。近 年では動機づけを高める方法を探索する研究(例えば, Dörnyei, 2001)も盛んだが, その中で特に注目されているのが「動機づけを高める方略」(motivational strategies) の研究である。

動機づけを高める方略とは, 授業の中で学習者の動機づけを高め, 維持する方 法やテクニックと定義される(Dörnyei, 2001)。この方略を扱った研究は大きく分けて, (1) 動機づけを高める方略を提案する研究，(2) 動機づけを高める方略の効果検 証を行う研究, の2つである。前者の研究は, 多様な動機づけ理論や今までの研究 蓄積を基に, 動機づけを高める方略を提示する研究である(例えば, Dörnyei, 2001; Williams \& Burden, 1997)。しかし教育現場での英語指導にそれらの方略を取り入れ た時, 方略は本当に動機づけを高める効果があるのか, という検証が十分なされて いなかった。特に海外での調査を基に作成された方略が, 日本人の英語学習者に効 果的なのか, そもそも日本の学校英語教育の環境に馴染む方略なのか, という点が 不明であった。このような問題点を踏まえて，(2)の動機づけを高める方略の効果検 証研究が行われるようになつた。 
動機づけを高める方略の効果検証研究では, 先行研究で得られた理論的知見を 基に, 動機づけを高める方略を考案したり, 先行研究で提示された方略を用いて, そ の方略の効果を実際の英語授業の中で検証する介入型研究が一般的である2。

例えば, 田中・廣森(2007) はグループによるプレゼンテーション活動を方略として 授業の中に取り入れ, 学習者の3欲求を満たす授業活動を行った。その結果, 介入の 前後でクラスの学習者全体の内発的動機づけを有意に高めた。また学習者をクラス ター分析によって高動機群, 低動機群, 中間動機群に分類することで方略の効果を 詳細に検証した結果, グループによるプレゼンテーション活動は特に低動機群の内 発的動機づけを顕著に高め, 高動機群の内発的動機づけを維持する効果があった。

またHiromori (2006)は, ライティング活動の中に“creative writing activities with student self-monitoring techniques”と名づけた方略を取り入れ, 内発的動機づけを高 める試みを行った。クラスター分析によって学習者を 4 つの群に細分化し, 方略の効果 を検討した結果, 外的調整と呼ばれる外発的動機づけに近い動機づけを持つた学習 者群と無動機群の学習者の内発的動機づけを高めたことが示された。

以上の研究例から, 動機づけを高める方略を取り入れた授業によって, 学習者の 動機づけを高めることができる点, 特に方略の効果は動機づけが低い学習者や無動 機の学習者に効果的である点が明らかになっている。

このように日本国内ではいくつかの研究成果がある一方で, 外国語教育の分野 全体では動機づけを高める方略の効果検証を行う研究の数はまだ少ない(例えば Dörnyei, 2001; Guilloteaux \& Dörnyei, 2008)。動機づけを高める研究は現在進行形 で進んでおり, 本論では今後の研究を進める上での問題点を2点指摘したい。

\section{動機づけ概念の細分化}

第1は, 動機づけ概念の定義の問題である。今までの動機づけを高める方略の効 果検証研究では, 学習者の英語学習一般に対する動機づけを高めようとしてきた。 例えば効果検証の際に, 動機づけの変動を測定する質問紙では, 「あなたが英語を 学習する理由は何ですか?」と問われる。この測定方法はある特定の授業などのコン テクストに特化した動機づけではなく, 学習者の英語学習全般への動機づけを測定 している。このような動機づけは「特性としての動機づけ」(trait motivation, Gardner \& Tremblay, 1998) と呼ばれる。しかし近年は, 動機づけを分析する単位が細分化され てきた。Crookes and Schmidt (1991)は, 外国語学習と動機づけの関連を扱うには, 動 機づけをこれまでの特性としての動機づけに一元化するのではなく, 4 つのレベルに 細分化することを提案している。それが，「ミクロレベル」(micro level),「授業レベル」 (classroom level),「シラバス・カリキュラムレベル」(syllabus/curricular level),「授業 外レベル」(outside-the-classroom level)である。あるいは, Dörnyei (1994)は動機づけ を「言語レベル」(language level),「学習者レベル」(learner level),「学習状況レベル」 (learning situation level)に細分化している。

同様に，内発的動機づけも近年はその概念の多元性が指摘されている。例え ば, Vallerand and Ratelle (2002)は, 動機づけの対象の一般性に着目した上で, 内発 的動機づけを3つのレベルに細分化している。最も一般性が低い対象を扱うミクロレ ベルの内発的動機づけを「状況レベル」(situational level), 最も一般性が高い対象を 扱うマクロレベルの内発的動機づけを「包括レベル」(global level), そして, その中間 を「コンテクスト・レベル」(contextual level) とした。このように内発的動機づけを細分 
化する利点として, 学習者のタスク活動に対する内発的動機づけ, あるいは英語学 習全体に対する内発的動機づけなど, 多様なレベルの動機づけを個別に検討できる 点が挙げられる。また, Vallerand and Ratelleはこれら 3 つのレベル分けを総合して「 階層モデル」(hierarchical model) と呼んでいる。この階層モデルは, 各レベルの内発 的動機づけが相互に影響し合っていると仮定している。つまり，下位レベルの内発的 動機づけがより上位レベルの内発的動機づけに影響を与えるボトムアップ効果と, 上 位レベルの内発的動機づけがより下位レベルの内発的動機づけに影響を与えるトッ プダウン効果である。

しかしながら, 外国語教育研究における動機づけを高める研究では, 動機づけを 一元的な概念として扱い, 特性的な動機づけを高めることを目指してきた。例えば, 田中(2005b), Hiromori (2006), 廣森・田中(2006), 田中・廣森(2007)では, 内発的 動機づけ, 同一視調整, 投入調整, 外的調整, 無動機など, 多様な動機づけ概念を 扱っているが, それらはすべて一般性の観点から細分化されておらず, 特性的な動 機づけである。

そこで本論では, 内発的動機づけを3つに細分化し, 3つのレベルの内発的動機づ けを高める試みを行う。それによって, 方略の効果を各レベルの内発的動機づけごと に検討可能になる。つまり, 方略がどのレベルの内発的動機づけを高めることができ るのかを明らかできる。

本論では, Vallerand and Ratelle (2002)の階層モデルを参考に, 内発的動機づけを 3つのレベルに細分化する。第1に比較的一般性の低いミクロレベルの内発的動機づ けとして, リスニング活動やスピーキング活動といった授業活動レベルに特化した内 発的動機づけ(以降,「リスニング活動への動機づけ」,「スピーキング活動への動機 づけ」), 第2に一般性の高いマクロレベルの内発的動機づけとして特性レベルの内発 的動機づけ (以降,「特性としての動機づけ」), 第3にその中間レベルの内発的動機 づけである, 英語授業レベルの内発的動機づけ(以降,「英語授業への動機づけ」), という3つのレベルの内発的動機づけを扱う(表1参照)。

仮に, ある方略が3つのレベルすべてに効果的だと示されれば, その方略は広く動 機づけを高める方略といえる。一方, 活動レベルだけに効果的であれば, 方略の効果 は限定的であるといえよう。

表1. 本論で扱う動機づけと主な先行研究で扱われた動機づけ

\begin{tabular}{|c|c|c|c|}
\hline & \multicolumn{3}{|c|}{ 一般性 } \\
\hline & 授業活動レベル & 英語授業レベル & 特性レベル \\
\hline 主な先行研究 & $x$ & $x$ & $\bigcirc$ \\
\hline 本論 & 0 & 0 & 0 \\
\hline
\end{tabular}

\section{測定時点}

第2の問題点として, 動機づけを高める方略の効果検証を行う際の測定回数につ いて指摘したい。今までの動機づけを高める研究では, 動機づけの変動をプレ測定 とポスト測定の2時点で捉えていた。Hiromori (2006)は12週間, 廣森・田中(2006)と 
田中・廣森(2007) は5週間の介入を行い, そのプレとポストでの動機づけの変動を捉 えた。

このようなプレ・ポストによる実験デザインは一般的だが,このデザインだけでは 介入の大まかな効果が把握できるだけで, それ以上の情報は得られない。つまり, プ レとポスト測定の結果, 動機づけが高まっていても, 介入の間に動機づけがどのよう に変動したかはブラックボックスの中である。介入を行っている間, 動機づけはずっと 上昇し続けるか, あるいは, 動機づけはいったん上昇しても, その上昇は介入の新規 性効果にすぎず, やがて動機づけは下がり始め, ある程度の水準まで戻ってしまうの か, などの情報はプレ・ポスト・デザインからは得られない。そこで本論では, プレとポ ス卜測定の間に中間測定を入れることで, 介入の効果の途中経過を把握し, 動機づ けの変動をより詳細に捉えることを目指す。

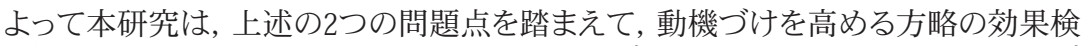
証を行う。より具体的には, 学習者の内発的動機づけを3つのレベルの内発的動機づ けに細分化する。そして大学生を対象に動機づけを高める方略を取り入れた授業実 践を行い, 3つのレベルの内発的動機づけの変動から, 動機づけを高める方略の効果 を検証する。その際に, 動機づけの測定にはプレ測定, ポスト測定に, 新たに中間測 定を加えた3時点で動機づけの変動を捉える。

\section{動機づけをを高める方略}

次に, 内発的動機づけを高める方略の設定を行う。内発的動機づけを高める方略 は数多く提案されているが, その中で効果検証が行われた方略の数は極めて限定さ れる。この中で, 菊池・中山(2006)は, 外国映画を教材として用いたリスニング活動 を方略として位置づけ, 中学生の動機づけを高める試みを行っている。外国映画をリ スニング教材として用いる利点として, 菊池らは, 学習者に生きた英語に接する機会 を与えられる点, 日常的に授業の教材として使用できる点, 会話のスピードの速さや 発音の不明瞭さはあるが, 意外に簡単な英語が用いられている点, などを挙げてい る。特に, この調査から外国映画を用いたリスニング活動によって, 中学生の内発的 興味を高めることができた点は興味深い。菊池らの調査は中学生を対象にした方略 の効果検証であったが, この方略は中学生以外の英語学習者にも有効である可能性 がある。よって本論では, 菊池らの方略を参考に, 大学生の 3 つのレベルの内発的動 機づけを高める試みを行う。

ただし, 菊池・中山(2006)の方略は中学生のリスニング活動を対象に設計されて いるため, 本論ではいくつかの改良を加えた。第1に, 菊池らの研究では外国映画をリ スニング活動の教材として用いたが, 本論では, スピーキング活動も行えるように設 計し直し, コミュニケーション活動教材として外国映画を用いた。動機づけを高める 方略とは, 単に動機づけを高めるだけの目的ではなく, カリキュラムやシラバスの中 で求められている英語学力を高める指導の一環として行われなければならない。近 年ではコミュニケーション能力の育成を目指すことが重要視されており, 外国映画を 単にリスニング活動だけに用いるのではなく, スピーキング活動も行えるように再設 計することで, この方略の教育的意義をより高められるように配慮した。

第2に, 菊池・中山(2006)では外国映画のみを教材の対象としたが, 本論では外国 ドラマも教材の対象に加えた。コミュニケーション活動を行うには, 学習目標となる表 現がどのような場面で, どのように使われているかが重要になる。表現が使われてい 
る場面が, 学習者の日常からかけ離れてしまっては, 表現のリアリティが失われてしま う。つまり, コミュニケーション教材として用いるには, 学習者が日常生活で接する可 能性の高い場面を, ある程度のストーリ一性を担保させながら提示する必要がある。 菊池らはTitanic, Matrix, Star Warsなどの作品から場面を切り出して調査を行った が, 本論ではより日常性の高い場面が多く登場する外国ドラマを中心に教材を作成 した。教材として取り上げた外国ドラマはFriendsである。Friendsはマンハッタンにす る男女6人の日常生活で起こる色々な出来事を題材にしたコメディー調のストーリー で, 1 話は22分程度である。その中で, 食事に誘う表現, レストランで料理を注文する 表現, 映画の感想を述べる表現などが頻出しており, コミュニケーション教材として 使用しやすいと判断した。映画はHarry PotterやKeeping the faithを用いた。

以上の点から, 本論では外国ドラマ・映画教材を用いたコミュニケーション活動を, 動機づけを高める方略として設定する。

\section{動機づけナを高める理論}

ここでは動機づけを高める方略の理論的な裏づけについて述べる。動機づけに関 する理論はこれまでに数多く提案されてきたが, 英語学習への動機づけを高める方 略を検討する場合,「自己決定理論」(Self-Determination Theory, Deci \& Ryan, 2002 , 以下SDTと略記)が参考になる。SDTでは内発的動機づけを高める要因として3つ の心理欲求を仮定している。「自律性の欲求」(the need for autonomy) とは, 自身の行 動がより自己決定的であり, 自己責任性を持ちたいという欲求,「有能性の欲求」(the need for competence) とは, 行動をやり遂げる自信や自己の能力を顕示する機会を持 ちたいという欲求,「関係性の欲求」(the need for relatedness) とは, 周りの人や社会 と密接な関係を持ち, 他者と友好的な連帯感を持ちたいという欲求, である。SDTで は, この3つの欲求が満たされることで, 内発的動機づけが高まるとしている。

この自己決定理論を理論的背景として用いる利点として, Dörnyei (1998)は(1)実 証的な手法によって, 理論の妥当性を検証できる点を挙げている。特に, 英語学習に おける動機づけ研究に適用した研究例が比較的多いため, 日本人の英語学習のコン テクストでの理論的妥当性が担保されていると考えられる。また，(2)動機づけを高め る要因を明確に提示している, (3)SDTの動機づけを高める要因は, 英語授業の中に 取り込みやすい, という点も挙げられる。

以上の理由から, 本論ではSDTを理論背景とし, 内発的動機づけを高める要因で ある3欲求を満たす形で, 授業の中に外国ドラマ・映画を用いたコミュニケーション活 動を取り入れる。

\section{目的}

本論の目的は学習者の3つのレベルの内発的動機づけを高めることにある。より具 体的には, 以下の6点である。

(1) 学習者の特性としての動機づけを高める。

（2）学習者の英語授業への動機づけを高める。

（3）学習者のスピーキング活動への動機づけを高める。

（4）学習者のリスニング活動への動機づけを高める。

（5）各レベルの内発的動機づけを高める要因を特定する。

（6）新たな動機づけを高める要因の探索を行う。 


\section{調査 \\ 調查協力者と手続き}

調査協力者は日本人大学生 52 名の内, 3 回の測定でデー夕の欠損がなかった 51 名 とした。調査協力者のTOEICの平均点は507点である。調査が行われた授業は1年次 の教養科目の必修授業であり, クラスサイズは52名である。この授業はリスニングを 中心にコミュニケーション活動を行うことを目的としている。学習者はTOEICの得点に 応じて習熟度分けされている。

動機づけを高める方略として, 外国ドラマと外国映画を用いたコミュニケーション 活動を行った。全15週の授業期間のうち, 第1回目, 第8回目, 第15回目に質問紙調査 を行った。調査はすべて当該授業を担当している教員によって行われた。第1回の授 業は調査に加えて, 授業の進め方の説明, CALL教室の機器の使用の説明, 課題の 提出方法などの説明を行い, 具体的な介入実験は第2回の授業から行われた。質問 紙調査の所要時間は15分程度であった。

\section{指導内容}

ここでは, 具体的にどのような指導を行い, それが動機づけを高める要因である SDTの3欲求にどのように関わっているのかを述べる。

授業では教材プリントを毎週1枚ずつ配布し, それを教科書の代わりとして使用し た。言語材料を機能別に配置し, 授業では自己紹介, 友人を紹介する表現, 人の性 格を描写する表現, 人の見た目を描写する表現, 誘う・待ち合わせる表現, 買い物を する表現, レストランを選ぶ表現, レストランで注文する表現,などを扱った。授業の 始めに重要表現を学習した後, それを使ったスピーキング活動やリスニング活動を行 つた。

授業の流れは, 言語材料の提示, スピーキング活動, リスニング活動という順番で ある。スピーキング活動では, 外国ドラマ・映画のシーンを基に作成したモデル・ダイ アログを提示し, それに沿ってペアで会話練習を行った。ここでは新出の言語材料の 定着を目的としている。次に, 学習者が言語材料の使用に慣れてきたタイミングを見 計らって, モデル・ダイアログから少し離れた発展的なスピーキング活動も取り入れる ことで, 応用的なスピーキング力の育成も目指した。リスニング活動は, 学習した言 語材料が用いられている外国ドラマ・映画のシーンを使った。言語材料が含まれてい るドラマ・映画のシーンでリスニングを行う前に, その場面のストーリーが理解できる 程度にその前のシーンを日本語字幕つきで視聴させた。該当シーンでは, 字幕を消し た状態でリスニングを行った。大意把握問題を行った後, ディクテーション活動を行っ た。

この活動と3欲求の関連であるが, まず学習者の自律性の欲求の充足に関しては, 授業の中で学習者のペースで学習できるように配慮した。特にリスニング活動時は, 各学習者に割り当てられたパソコンを使った。ネットワーク上に音声ファイルを事前に 用意し, 授業時間内で学習者にそれをダウンロードさせた。その後, 各パソコンに付 いているへッドセットを用いてリスニング学習を行わせた。これにより, 学習者は聞き 取りにくかった箇所を何度も繰り返して聞くことができ, 自分自身のリスニングカに合 わせた学習が可能になった。また音声ファイルは学習者個人のUSBメモリに保存させ ることで, 自宅での自主的学習も可能にした。スピーキング活動ではペア活動を中心 
にタスク活動を行った。ただペアによってタスクをこなすスピードに差があることから， 早く終わったペアには応用タスクも準備し, 各ペアの学習速度にあわせて学習活動が 進められるようにした。

有能性に関しては, 外国ドラマ・映画のリスニングという難易度の高いチャレンジン グな課題を与え, それを達成することで達成感や有能感を感じられるように配慮し た。外国ドラマ・映画は自然な速度で英語が話されるため, 学習者が英語の速度に慣 れるまでは, かなり難易度の高い活動である。しかし, 実際に会話で使われている語 や表現は学習者が中学や高校で既習のものが多い。また学習者にとつて新規学習事 項を事前に授業で取り扱うことで, リスニングを行う場面に未習事項が含まれないよ うにした。スピーキング活動では, 言語材料を単に提示するのではなく, 会話の流れ の中でどのように表現すると英語らしくなるかや，日常の何気ない言葉を英語にする とどうなるか, と問うなど, 学習者の知的好奇心を喚起するように配慮して指導した。 またペア活動を通して, 繰り返し言語材料を練習することで, 言語材料に慣れさせる だけでなく, それを使った応用的な活動も入れることで, より学習者に言語材料が定 着しやすくなるように指導をした。

関係性の欲求に関しては, ペアでのスピーキング活動を主にすることで, 学び合う 雾囲気を作るようにした。座席は第1回の授業で学習者の友人同士で座らせ, その 後はその席に固定した。座席の隣同士でペアを組ませ, 仲の良い友人同士でのスピ 一キング活動によって, 英語を話しやすい雾囲気になるように工夫した。ペア活動中 は, 教員は机間巡視指導を行い, 適宜, 学習者にアドバイスを行った。リスニング活 動中は, 学習者がパソコンを使っての個人学習のため, クラスメイトとの関わりはなく なる。しかし教員が机間巡視指導を行って, 学習者の誤りやつまずきに対してアドバ イスを与えることで, 教員に質問しやすい雾囲気を作り, 関係性の欲求に配慮した。

\section{測定}

測定には7件法(1を「まったく違う」, 7を「まったくその通り」)の質問紙を用いた。 質問紙は3つの部門に分かれている3。第1部は動機づけの測定で, 3つのレベルの内 発的動機づけを測定するものである。特性としての動機づけの測定には, Academic Motivation Scale(Vallerand, Pelletier, Blais, Briere, Senecal, \& Vallieres, 1992)を参考 に, 対象となる調査協力者の実態を反映しているかどうかに留意しながら項目を設定 した $(\alpha=.83, .85, .87)^{4}$ 。授業活動への動機づけの項目は, 本調査のために作成し た。リスニング $(\alpha=.86, .91, .88)$ とスピーキング( $\alpha=.89, .89, .92)$ のつの観点から 各3項目で測定を行った。英語授業への動機づけは, 先行研究 (田中, 2005a, 2006)に 基づきながら, 調査協力者の実態に配慮して項目を設定した。質問項目は4項目であ る $(\alpha=.90, .92, .96)$ 。

第2部は3欲求に関する質問項目である。質問紙は田中・廣森(2007)を参考に, 自 律性 ( $\alpha=.74, .84, .86)$, 有能性 $(\alpha=.90, .87, .80)$, 関係性 $(\alpha=.93, .89, .94)$ の 3 つ の欲求を各4項目から測定している。

第3部は自由記述で, 学習者の授業の感想と自身の授業での学習の取り組みを問 うものである。本調査では統制群を置かずに, 実験群のみで介入の効果を捉えようと している。このように自然発生的なクラスを便宜上の実験群とするのは, より実践に 近い形での方略の効果検証を目指す本論の目的を達するためである。しかし, 単なる プレとポストによる動機づけの量的な変化だけでは, 実験群を置くデザインほど明示 
的に介入の効果を示すことは難しい。そこで, 量的研究だけでなく, 学習者の自由記 述デー夕を分析する質的研究を加えることで, 可能な限り介入の効果を明示的に捉 え, 動機づけの変動の背景を明らかにできるようにした。

調査協力者には, 外国ドラマ・映画を使ったコミュニケーション活動の感想, 及び自 身の学習の取組みの自己評価という2つの項目を設定し, それぞれスピーキング活動 とリスニング活動に分けて回答させた。自由記述データは第3時点のみ収集した。

\section{分析}

量的データの分析には, SPSS15.0Jを用いて, 記述統計量, 対応のある一要因分散 分析, およびピアソンの相関係数を算出した。

質的デー夕はアイデア・ユニットに分類した上で, KJ法(川喜田，1967，1970)年 用いた解釈による分析を行った。KJ法では, 質的デー夕を文字データの形にした後 に, 1つの意味のある文章のまとまりを1つの単位として切り出し, アイデア・ユニット としてカード化する。こうしてできた多量のカードを意味のまとまりごとにグループを 作り, 図解をしていくことで仮説を生み出そうとする方法である。この図解の作業を A 型図解と呼ぶ。さらに仮説を生み出す際に図解したものを再度文章化することを B型文章型と呼ぶ。類似した質的データの分析方法にグランデッド・セオリー・アプロ 一チ(Grounded Theory Approach, Glaser \& Strauss, 1967, 以下GTAと略記)がある が, GTAと比較してKJ法は, 解釈における創造性やアウトプットの具体性が高いこと から, 本論の目的に合致している方法と判断した。

質的分析を行う際は, 結果の解釈の妥当性を問われることが多い。本論では累積 的KJ法を採用することで, より妥当なデー夕解釈を目指した。累積的KJ法とは, A型 図解 $\rightarrow B$ 型文章化で終了する通常のKJ法とは異なり, A型図解 $\rightarrow B$ 型文章化のあと に, さらにA型図解 $\rightarrow \mathrm{B}$ 型文章化のプロセスを繰り返す方法である(川喜田, 1967)。ま たKJ法を行う際は, 本論の執筆者以外の英語教育学の専門知識のある英語教員とと もに分析を行い, 解釈の独断性を軽減できるように配慮した。

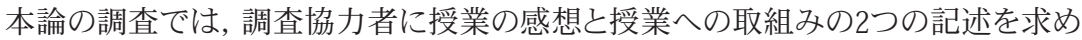
たが, 調査協力者はこの2つを混同して記述している場合が多かった。よって本論で は2つを区別せずに分析した。

\section{結果}

\section{動機づけを高める方略の効果検証}

動機づけを高める方略の効果を検証するため, 3つのレベルの内発的動機づけ及 び3欲求の記述統計量(表2参照, 及び図1参照)を検討した 6 。

まず授業活動レベルでの内発的動機づけの変動を検討する。リスニング活動へ の動機づけは, 介入の前 (第 1 時点) から後(第3時点)で, 平均値の上昇が見られた $\left(M_{\text {diff }}=0.48, F(2,50)=9.44, p=.00\right)$ 。より詳細に検討すると, 第1時点から第2時 点にかけて上昇した後 $\left(M_{\text {diff }}=0.35\right)$, 第2時点から第3時点にかけては微増した $\left(M_{\text {diff }}\right.$ $=0.13)$ 。ボンフェローニの方法による多重比較では, 第1時点目から第2時点目, 第1 時点目から第3時点目でのリスニング活動への動機づけの上昇が5\%水準で有意であ つた。

スピーキング活動への動機づけは, 介入の前後での上昇が見られた $\left(M_{\text {diff }}=0.39, F\right.$ $(2,50)=8.82, p=.00)$ 。より詳細には, 第1時点から第2時点にかけて上昇した後 $\left(M_{\text {diff }}\right.$ 
$=0.58)$, 第2時点から第3時点において減少した $\left(M_{\text {diff }}=-0.20\right)$ 。ボンフエローニの方 法による多重比較の結果, 第1時点目から第2時点目, 第1時点目から第3時点目での スピーキング活動への動機づけの上昇が5\%水準で有意であった。

次に授業レベルでの内発的動機づけを検討する。英語授業への動機づけは介入 の前後で上昇した $\left(M_{\text {diff }}=0.49, F(2,50)=13.64, p=.00\right)$ 。より詳細には, 第1時点か ら第2時点にかけて, 平均值が著しく上昇しており $\left(M_{\text {diff }}=0.45\right)$, その後の第2時点か ら第3時点まではほぼ無変化であった $\left(M_{\text {diff }}=0.04\right)$ 。ボンフェロー二の方法による多 重比較の結果から, 第1時点目から第2時点目, 第1時点目から第3時点目での英語授 業への動機づけの上昇が5\%水準で有意であった。

表2.3つのレベルの内発的動機づけと3欲求の記述統計量

\begin{tabular}{|c|c|c|c|c|c|}
\hline & & 時点 & $M$ & $S D$ & $M_{\text {diff }}$ \\
\hline \multirow{6}{*}{ 授業活動レベル } & \multirow{3}{*}{ リスニング } & 1 & 5.15 & 0.95 & \\
\hline & & 2 & 5.50 & 0.87 & 0.35 \\
\hline & & 3 & 5.63 & 0.84 & 0.48 \\
\hline & \multirow{3}{*}{ スピーキング } & 1 & 4.39 & 1.10 & \\
\hline & & 2 & 4.97 & 0.90 & 0.58 \\
\hline & & 3 & 4.77 & 1.04 & 0.38 \\
\hline \multirow{3}{*}{ 英語授業レベル } & \multirow{3}{*}{ 英語授業への動機づけ } & 1 & 3.68 & 1.06 & \\
\hline & & 2 & 4.13 & 1.07 & 0.45 \\
\hline & & 3 & 4.17 & 1.24 & 0.49 \\
\hline \multirow{3}{*}{ 特性レベル } & \multirow{3}{*}{ 特性としての動機づけ } & 1 & 4.89 & 1.03 & \\
\hline & & 2 & 4.91 & 1.00 & 0.02 \\
\hline & & 3 & 4.79 & 1.00 & -0.10 \\
\hline \multirow{9}{*}{ 3欲求 } & \multirow{3}{*}{ 自律性 } & 1 & 3.68 & 0.83 & \\
\hline & & 2 & 4.33 & 0.98 & 0.65 \\
\hline & & 3 & 4.54 & 1.02 & 0.86 \\
\hline & \multirow{3}{*}{ 有能性 } & 1 & 3.88 & 1.06 & \\
\hline & & 2 & 4.01 & 0.91 & 0.13 \\
\hline & & 3 & 4.23 & 1.02 & 0.35 \\
\hline & \multirow{3}{*}{ 関係性 } & 1 & 4.27 & 1.12 & \\
\hline & & 2 & 4.66 & 0.90 & 0.39 \\
\hline & & 3 & 4.85 & 1.08 & 0.58 \\
\hline
\end{tabular}

Note. $M_{\text {diff }}$ は第1時点を基準に算出。

最も一般性の高いレベルの内発的動機づけである特性としての動機づけは, 介入 の前後において, ほぼ無変化だつた $\left.\left(M_{\text {diff }}=-0.10, S F(2,50)=1.19, p=.31\right)\right)$ 。第1時 点から第2時点 $\left(M_{\text {diff }}=0.02\right)$, 第2時点から第3時点 $\left(M_{\text {diff }}=-0.12\right)$ までの間でも, 大き な変動は見られなかった。

以上の点から, 動機づけを高める方略によって, リスニング活動への動機づけ, ス 
ピーキング活動への動機づけ, 英語授業への動機づけが高まった。これら3つの内発 的動機づけは, 第1時点から第2時点に顕著な高まりを見せ, 第2時点から第3時点で は, ゆるやかな変動に変化することが示された。一方, 特性としての動機づけには変 化がなく, 動機づけを高める方略の効果は見られなかった。

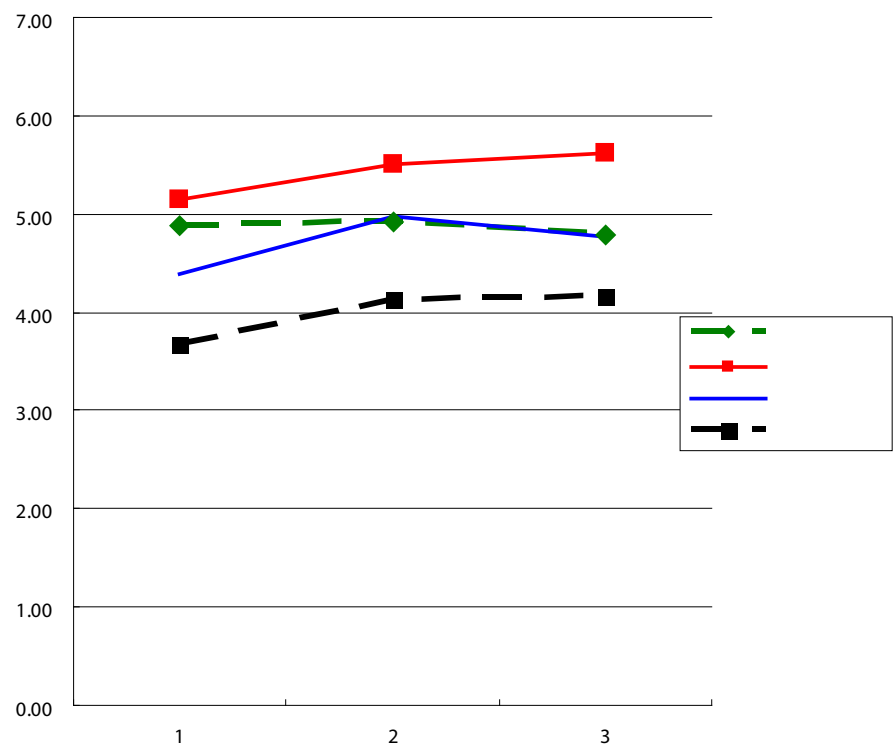

時点

図1. 介入前後の内発的動機づけの平均值の変動

\section{動機づけを高める要因に関する検討}

次に動機づけを高める要因である3欲求の検討を行う。まず動機づけを高める方 略の効果を検証するために, 記述統計量を基に3時点での3欲求の変動を検討した( 表2参照)。

その結果, 自律性 $\left(M_{\text {diff }}=0.86\right)$ と関係性 $\left(M_{\text {diff }}=0.58\right)$ は介入の前後で大きな高まり を見せた。第1時点から第2時点にかけて自律性 $\left(M_{\text {diff }}=0.65\right)$, 関係性 $\left(M_{\text {diff }}=0.39\right)$ は 共に上昇した後, 第2時点から第3時点にかけて緩やかな上昇に移行した(自律性は $M_{\text {diff }}=0.21$, 関係性は $\mathrm{M}_{\text {diff }}=0.19$, 表2参照, 及び図2参照)。対応のある一要因分散分 析の結果, 自律性 $(F(2,50)=24.00, p=.00)$, 関係性 $(F(2,50)=12.98, p=.00)$, 共 に主効果は $5 \%$ 水準で有意であった。ボンフェロー二の方法を用いて多重比較を行っ たところ, 第1時点目から第2時点目, 第1時点目から第3時点目では, $5 \%$ 水準で有意 であった。 
一方, 有能性は介入の前後で緩やかに上昇していた $\left(M_{\text {diff }}=0.35\right)$ 。第 1 時点から第 2 時点にかけて $\left(M_{\text {diff }}=0.13\right)$, 第2時点から第3時点にかけて $\left(M_{\text {diff }}=0.22\right)$, 継続的に 微増していた。主効果は5\%水準で有意であったものの $(F(2,50)=3.96, p=.02)$, ボ ンフェローニの方法による多重比較では第1時点目から第3時点目にかけて有意差傾 向がみられたのみであった。

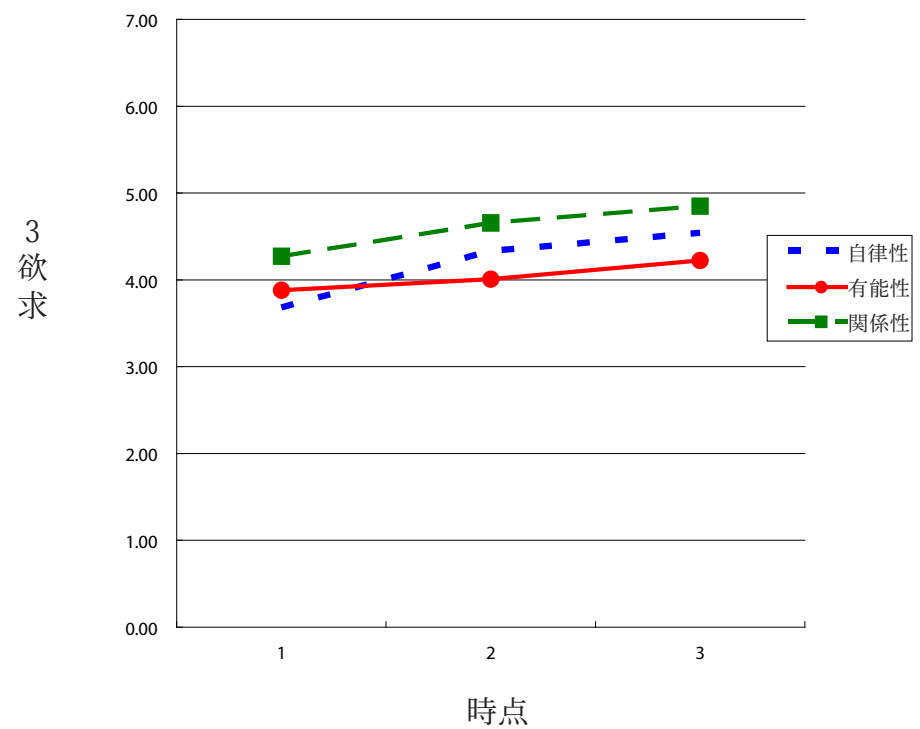

図2. 介入前後の 3 欲求の平均値の変動

次に相関係数を基に, 3 欲求の上昇が3つのレベルの内発的動機づけの上昇とどの ように関連しているかを検討する(表3参照)。またVandergrift (2005)に従い, 効果量 を算出することで, Type I errorsへの対処を行った。相関係数の算出の際は, プレ測 定からポスト測定の得点を減ずることで変化量とみなし, 各変数の変化量間での相 関係数を求めた。

まずリスニング活動への動機づけの変動には, 第1時点から第3時点までの全体を 見ると, 有能性との関連性がやや強く $(r=.39)$, 自律性 $(r=.15)$ と関係性 $(r=.10)$ の 関連性はそれほど強くなかった。より詳細には, 第1時点から第2時点では, 有能性が $r=.34$, 自律性が $\mathrm{r}=.10$, 関係性が $r=.24$, 第2時点から第3時点では有能性が $r=.12$, 自律性が $r=.11$, 関係性が $r=.32$ であった。

スピーキング活動への動機づけの上昇には, 第1時点から第3時点までの全体を見 ると, 関係性 $(r=.41)$ と有能性 $(r=.34)$ の上昇が関連していた。より詳細には, 第1時 点から第2時点では, 関係性が, $r=.38$, 有能性が $\mathrm{r}=.28$, 第2時点から第3時点におい ては, 関係性が, $r=.52$, 有能性が $r=.06$ であった。 
表3. 3つのレベルの内発的動機づけと3欲求の相関係数, および効果量

\begin{tabular}{lccccccc}
\hline & 特性 & $\mathrm{L}$ & $\mathrm{S}$ & 授業 & 自律 & 有能 & 関係 \\
\hline 特性 & - & $.03 / .03 / .04$ & $.03 / .01 / .08$ & $.10 / .01 / .06$ & $.06 / .00 / .02$ & $.25 / .04 / .08$ & $.02 / .00 / .06$ \\
$\mathrm{~L}$ & $.17 / .16 / .21$ & - & $.19 / .16 / .23$ & $.13 / .05 / .02$ & $.02 / .01 / .01$ & $.15 / .12 / .01$ & $.01 / .06 / .10$ \\
$\mathrm{~S}$ & $.16 / .11 / .28 *$ & $.44^{*} / .40^{*} / .48^{*}$ & - & $.35 / .26 / .26$ & $.02 / .00 / .07$ & $.12 / .08 / .00$ & $.17 / .14 / .27$ \\
授業 & $.32 * / .11 / .25$ & $.36 * / .23 / .13$ & $.59 * / .51^{*} / .51^{*}$ & - & $.28 / .18 / .26$ & $.29 / .18 / .03$ & $.22 / .14 / .27$ \\
自律 & $.24 / .06 / .15$ & $.15 / .10 / .11$ & $.14 / .08 / .27$ & $.53^{*} / .42^{*} / .51 *$ & - & $.11 / .07 / .04$ & $.02 / .01 / .05$ \\
有能 & $.50 * / .21 / .29 *$ & $.39 * / .34 * / .12$ & $.34^{*} / .28 * / .06$ & $.54^{*} / .43 * / .16$ & $.33 * / .26 / .20$ & - & $.03 / .08 / .07$ \\
関係 & $.15 / .02 / .25$ & $.10 / .24 / .32 *$ & $.41^{*} / .38^{*} / .52^{*}$ & $.47^{*} / .37^{*} / .52^{*}$ & $.13 / .11 / .22$ & $.18 / .14 / .26$ & - \\
\hline
\end{tabular}

Note. * は5\%水準で有意

表記は1時点-3時点/ 1 時点-2時点/ 2 時点-3時点。上段は効果量。

Lはリスニング活動への動機づけ, Sはスピーキング活動への動機づけ

英語授業への動機づけの上昇には, 第1時点から第3時点までの全体を見ると, 自 律性 $(r=.53)$, 有能性 $(r=.54)$, 関係性 $(r=.47)$ の3欲求の上昇が満遍なく関連して いた。より詳細には, 第1時点から第2時点では, 自律性が $r=.42$, 有能性が $r=.43$, 関 係性が $r=.37$, 第2時点から第3時点においては, 自律性が $r=.51$, 有能性が $r=.16$, 関係性が $r=.52$ であった。

以上の点から, リスニング活動への動機づけの上昇には有能性の欲求が, スピー キング活動への動機づけの上昇には, 有能性と関係性が, 英語授業への動機づけの 上昇には3欲求が満遍なく関わっていることが示された。ただし, 上記の3つの動機づ けすべてに対して, 第2時点から第3時点の間の有能性の変化量だけが, 他の時点と 比べて関連性が弱くなっていた。

\section{自由記述の検討}

\section{リスニング活動への動機づけ}

リスニング活動に対する調査協力者の感想と取組みの自己評価に関する記述をア イデア・ユニットごとに分類した結果，134のアイデア・ユニットが得られた。累積的KJ 法による最終的なA型図解がAppendix Aである。

まず外国ドラマ・映画のリスニングは, 著者が想定したとおり, 難易度の高い活動 であった(カテゴリー(1)「難しさ」)。「上手に聞き取れないことも結構あった」という記 述から, 調査協力者は自然な速度の英語を聞き取ることに, かなり苦労したことが分 かる。しかしその一方で, 調査協力者は難易度の高い課題に「やりがい」も感じていた ことが分かる(カテゴリー(2)「チャレンジ」)。例えば,「自然な英会話を聞き取れたよう な気がして, 難しかったけど, やりがいがありました」という記述から, 調査協力者は 聞き取ろうと集中してリスニングの課題に取り組み, たとえ難しくても, 聞くことが楽し いとも感じていたと判断できる。また自然な英語に触れる事にも調査協力者は好意 的であったようだ(カテゴリー(3)「自然な英語に触れられることへの評価」)。「速度が 速くて大変だったが, 英語を母国語とする人の速さなので良い」といった記述が見ら 
れた。また通常のリスニングとは異なり, 映像を伴うことから, その映像がリスニング のヒントになったり,リスニング内容に対する学習者の興味を喚起したようだ(カテゴ リー(4)「映像の効果」)。授業で教材に扱った外国ドラマ・映画のストーリ一自体の面白 さ(カテゴリー6「「ストーリー自体の面白さ」), 使われる表現が日常生活で使える表現 であったことも(カテゴリー5「実用性」)，調査協力者には肯定的に受け止められたよ うだ。

このような肯定的要因が作用して, 調査協力者はリスニング活動を楽しいと感じ( カテゴリー(7)「楽しみ」), リスニング活動への動機づけが高まったと考えられる(カテ ゴリー8「聞く意欲の促進」)。「ただ英文を聞くよりも, ストーリーがある方が興味を持 って楽しく行うことができました」といった, 聞く楽しさや,「話を理解したいという思い があったので, 特に真剣に取り組めたと思います」といった記述から, 調査協力者はス トーリーを理解したい気持ちを持ってリスニング活動に取り組んでいたと考えられる。 これにより, 調査協力者はリスニング活動に積極的に取り組むようになったのだろう( カテゴリー9「積極的取組み」)。調查協力者は聞き取ろうと努力し, 英語を聞き取れ るまで非常に集中し, 繰り返し聞いた。「難しかったけど, 聞き取れるように努力した と思う」や「最初は嫌いだったけど, 聞き取るためにがんばろうと思うようになった」と いった, 意欲的な態度への変化を表す記述も見られた。中には「自分でもこれから外 国の映画やドラマを使ってリスニングをしてみよう」といった積極性を伺わせる記述も あった。これらの積極的な取組みによって,「後半あたりからはあまり大変でなくなり ました」という記述に代表されるように, 調査協力者が外国ドラマや映画の聞き取りに 慣れてきたことが同える。やがて調査協力者は「段々と聞き取れるようになっていった のが感じれて非常にうれしかった」と感じるようになり, 有能感を獲得していったと考 えられる(カテゴリー(10「有能感」)。

\section{スピーキング活動への動機づけ}

スピーキング活動に対する調査協力者の感想と取組みの自己評価に関する記述 をアイデア・ユニットごとに分類した結果, 128のアイデア・ユニットが得られた。累積 的KJ法による最終的なA型図解がAppendix Bである。

スピーキング活動は主にペア活動が主体だったが, 調査協力者はペア活動を好意 的に受け止めた(カテゴリー(1)「ペア活動の効能」)。特に「仲間うちでの会話が多かつ たので, 緊張せずに会話できた」という記述に見られるように, 友人とのスピーキング 練習によって, 英語を話すことへの緊張が解消されたことが伺える。また, スピーキン グ活動では日常生活で使う表現を中心に扱ったため, 調査協力者は学習内容に実用 性を感じた(カテゴリー(2)「実用性」)。調査協力者の記述には「日常的なシーンの英会 話で(登場人物に)なりきりやすく, 使えそうなフレーズばかりでよかった」や「れから 先役に立つ」が見られた。このことから, 海外ドラマ・映画を使ったスピーキング活動に 対して, 調査協力者は「おもしろかった」や「やっていて楽しかった」というような好意的 感情に加えて, 自然な状況で話される英語に対する興味も持つようになったと考えら れる。また教材の面白さだけでなく, 授業で使ったドラマ・映画自体のストーリ一の面白 さも, 調査協力者の話す意欲を刺激したようだ。調査協力者の「授業での, ペア練習 も意欲的に取り組めたと思います」や，「実用的な内容だったので使えるようになりた いなと思って取り組んだ」,「ドラマや映画の中での会話は親しみやすく, 私自身も固く ならずに会話することができた」といった記述に見られるように, 調査協力者はぺア活 動, 実用性, おもしろさ·興味, といった要因が肯定的に作用し, スピーキング活動に 
対する取組みが促進されたと考えられる(カテゴリー(5)「取組みの促進」)。

このようにスピーキング活動への動機づけが高まった調査協力者は,「定型的な表 現を覚えて使えるようになろうと覚えた」や「発音に気をつけて䪹張った」という記述 から, 授業に集中して取り組んだと考えられる。中には「もし自分がこの場面に遭遇し たら・..などと考えながら取り組めた」という記述が見られたように, 学習課題を自分 自身に取り込み，それを応用しようとする努力を行った調査協力者もいた(カテゴリー (7)積極的取組み)。このような積極的取組みによって, 調査協力者は「最近は少し話 せるようになってきた」と感じたり,「会話内のかなりくだけた表現や, 英語圈の表現 方法を知れてよかった」と感じるなど, 学習成果を肌で感じるようになった。また「どの ような場面で使うのかを, ドラマなど視覚的にも学ぶことができたのでためになった」 という記述に見られるように, 授業で学んだ日常会話などの表現とそれを使う場面を 結びつけて学習できたようだ。このように調査協力者はスピーキング活動に積極的に 取り組むことで, 少しずつ学習成果を実感し, 有能感を感じていたことが分かる。

有能感の記述とは対照的に,「あまり力が付かなかったと思う」といった記述も見ら れた(カテゴリー11「カがつかなかった」)。スピーキング活動の中で, モデル・ダイアロ グを使った会話はできても, それを基に新しい会話を続けていくことができなかった り(カテゴリー12「会話を発展できない」)，「英会話は相手の顔を見ながら話すことが できず，文章を見ないで話すことが難しかった」と感じたり(カテゴリー113「相手を見 れない」), あるいはモデル・ダイアログや例文を「棒読みにならないように, 気をつけ てやっていたつもりではなるが, なかなか上手くいかない」こがあったようだ(カテゴ リー(13)「棒読み」)。またリスニング活動と比較すると, スピーキング活動には積極的に 取り組めなかったり(カテゴリー8「「積極的に取り組めなかった」), 英語を話すことに 恥ずかしさを感じている調査協力者もいた(カテゴリー〔6「恥ずかしさ」)。

\section{考察}

本論では動機づけを高める方略の効果検証を行った。その際に, 内発的動機づけ を細分化し, 3 つのレベルに分けて方略の効果を検証した結果, 外国ドラマ・映画を 用いたコミュニケーション活動という方略が単に内発的動機づけを高めるという結果 だけでなく, どのレベルまでの内発的動機づけに影響を与えるかを示すことができ た。

まず, 外国ドラマ・映画を用いたコミュニケーション活動は3つのレベルの内発的動 機づけの内, 授業活動レベルの内発的動機づけと英語授業への動機づけを高める 効果があった。しかし最もマクロレベルの特性としての動機づけは, 介入の前後でも 無変化であり, 方略の効果が及ばなかった。このことから, 外国ドラマ・映画を用いた コミュニケーション活動は特性としての動機づけには十分な効果は見られなかった が, 授業活動レベルの内発的動機づけと英語授業レベルの動機づけを高める働きは あると言えよう。

この結果は, Vallerand and Rattle (2002)のボトムアップ効果によって説明が可能で

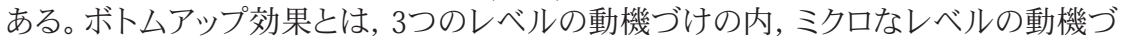
けが高まれば, その影響を受けて, より上位にある動機づけも高まる。さらに, それが 最もマクロなレベルの動機づけにも影響を与え, その動機づけも高まる, という関係 である。この枠組みに沿って本論の結果を説明すると, 外国ドラマ・映画を用いたコミ ユニケーション活動は, まず最もミクロなレベルである授業活動レベルの内発的動機 
づけを高めたことになる。授業活動レベルの内発的動機づけが高まったことで, その 効果が授業レベルの内発的動機づけに波及し, 英語授業への動機づけが高まったと 考えられる。しかし, そのボトムアップ効果はここまでで, より上位の特性としての動 機づけには, その効果が及ばなかったと解釈できる。

第2に, 本論では3つのレベルの動機づけの変動に貢献した要因を特定する試みを 行った結果, 各レベルの動機づけによって3欲求の機能が異なる, という結果を得た。 ただし, 3つのレベルの内, 特性としての動機づけはほぼ無変化であったので, ここで は授業活動レベルの内発的動機づけ(リスニング活動への動機づけ, スピーキング活 動への動機づけ) と授業レベルの内発的動機づけ(英語授業への動機づけ)の2つの レベルの内発的動機づけを高めた要因について考察する。

まず第1時点から第3時点までをトータルで検討すると, リスニング活動への動機 づけの上昇と関連が強かったのは, 有能性の欲求であった。このことから, 調査協力 者は有能感を獲得することで, リスニング活動への動機づけを高めていったと考えら れる。一方, スピーキング活動への動機づけの上昇と関連が強かったのは有能性に 加え, 関係性の欲求も含まれていた。このことから, 調査協力者は有能感を獲得し, さ らにクラス内で学びあう雾囲気ができることによって, スピーキング活動への動機づ けを高めていったと考えられる。次に授業レベルの内発的動機づけである英語授業 への動機づけの上昇の背景にあるのは, 調査協力者の3欲求すべての充足であった。 このことから, 活動レベルの内発的動機づけとは異なり, 3 つの欲求すべての上昇が 英語授業への動機づけの上昇に関連していたと言えよう。

以上の点から, 3 欲求の機能の仕方が, 内発的動機づけのレベルによって異なる 事が示された。ミクロレベルの内発的動機づけである授業活動への動機づけは, 授 業で行われる学習活動に直結した内発的動機づけである。そのため, どのようなス夕 イルで学習活動が行われたかに応じて, 3欲求の機能の仕方が変化する可能性があ る。一方の英語授業への動機づけに関しては, 授業活動レベルの内発的動機づけを 内包する, より上位のレベルの内発的動機づけである。1つの授業は多様な学習活動 の総和で構成されているため, 3欲求のバランスの取れた充足が英語授業への動機 づけの高揚に重要であったと考えられる。

このように第1時点から第3時点までの動機づけと3欲求の変動をトータルで捉える と, 有能性と関係性の欲求が重要であることが示された。しかし本論では第1時点か ら第3時点の間に中間測定を入れることで, 従来のプレ・ポスト・デザインよりも詳細 に動機づけの変動を把握できるようにした。その結果, 半期授業の前半 (第1時点か ら第2時点) と後半 (第2時点から第3時点)では, 動機づけの变動に関連する3欲求が 異なることが示された。英語授業への動機づけ, 及び, 授業活動への動機づけ(リス ニングとスピーキング)を高めるには, 授業の前半では有能性の欲求が重要な働きを するものの, 授業の後半になると, 有能性の欲求の重要性が低下し, 関係性の欲求 が重要な要因となった。この傾向はリスニング活動への動機づけ (有能性は $r=.34$ か $ら r=.12$, 関係性は $r=.24 か ら r=.32)$, スピーキング活動への動機づけ(有能性は $r=$ .28 から $r=.06$, 関係性は $r=.38$ から $r=.52)$, 英語授業への動機づけ $($ 有能性は $r=.43$ から $r=.37$, 関係性は $r=.16$ から $r=.52)$ のつで共通していた。以上の点から, 授業の 前半, いわいる新学期から中間テストの時期までは有能感という個人レベルの要因 が動機づけの高揚に重要であるが, 後半の授業, いわいる中間から期末テストまでの 授業に差し掛かると, 動機づけのさらなる維持・高揚には, クラスの雰囲気という集団 レベルの要因が重要であることが示された7。 
第3に, 本論では, 方略の効果検証を量的研究だけでなく, 質的研究からも検証を 行うことで, 量的研究の結果を補完する知見に加えて, 量的研究では把握し切れな かった内発的動機づけを高める新しい側面に関する知見も得られた。

まず量的研究の結果を裏づけ, 補完する部分について論じる。量的研究の結果, スピーキング活動への動機づけとリスニング活動への動機づけに共通したのは, 有 能性の欲求の充足が重要な動機づけを高める要因である点であった。質的デー夕を 分析したところ,「段々と聞き取れるようになっていったのが感じれて非常にうれしか った」という記述に代表されるように, 学習者の有能感の獲得が動機づけを高めるた めに重要であると考えらる。この質的研究の結果は量的研究の結果を裏付けるもの である。ただ, 量的研究からは有能性の欲求の変動はそれほど大きくなかったが, 質 的研究では有能性の記述が他の3欲求の記述よりも多く見られた。量的研究で用いら れた質問紙からは学習者の有能性の欲求はそれほど顕著に満たされていないと判断 されたが, 質的研究の結果を併せると, 学習者がある程度の有能感を獲得しているも のの, それが量的研究で用いられた質問紙では十分に捉えきれていなかった可能性 が生じる。今後は有能感をより適切に捉えられるように質問項目を精査する必要があ ろう。

またスピーキング活動への動機づけでは, 量的研究の結果, 関係性の欲求の上昇 が重要な役割をしていることが示された。この点は,「仲間うちでの会話が多かったの で, 緊張せずに会話できた」という記述に代表されるように, ペア活動が肯定的に作 用したという結果が得られ, 量的研究の結果を裏付けるものとなった。

一方で, 量的研究では見逃されていた, 新たな動機づけを高める要因も見出され た。スピーキング活動においては, 自由記述から実用性の付与が重要な要因だと示 された。ただ, 実用性は一般的に外発的動機づけを誘発し, 内発的動機づけを低下 させると考えることが多い。しかしSDTの理論的枠組みでは, 実用性の価值が学習者 個人の中に十分に取り入れられ内在化している場合と, 内在化していない場合では, 動機づけに与える影響は異なると考える(Deci \& Ryan, 2002)。学習者の中に価值が 取り入れられていなければ, その価值は自己決定されておらず, 内発的動機づけの 低下につながる。一方, 価値が学習者個人の中に十分に内在化していれば, その価 值は自己決定されており, 内発的動機づけの低下にはつながらず, むしろ内発的動 機づけに極めて近い動機づけである「同一視調整」(identified regulation)や「統合調 整」(integrated regulation)を高めるとしている。よって, 本論の調査協力者の一人が「 これから先役に立つ」と述べているが,これが学習者の中に十分に内在化した目標に 対して役に立つと述べているのであれば, 内発的動機づけに近い自己決定した動機 づけの促進につながった可能性がある。

\section{限界点と今後の課題}

最後に, 本論の限界と今後の課題として, 以下の7点を指摘しておく。

第1に, 本論では動機づけが高まる過程を捉えるためにSDTを用いた。しかしSDT が内発的動機づけの高まる過程を説明する唯一の理論ではない。今後は多様な理 論を取り入れながら, 包括的に内発的動機づけを高める方略の効果を検証する必要 がある。

第2に自由記述データの分析から, 有能性に関連する記述が多々見られた。しかし 質問紙調査からは有能性の欲求の変動は有意傾向が見られたのみで, 3 欲求の中で 
最も上昇值が低かった。これは, 本論で用いた有能性を捉える質問項目が, 本論で用 いた方略による有能性の変動を捉えるには不十分であった可能性が指摘される。こ の項目は先行研究で因子分析などの量的研究を繰り返して行った上で作成された項 目であり, ある程度の妥当性は確保されていると考えられる。しかし本論で行った調 査での有能性の変動を捉えるには, より項目を精査する必要があろう。今後は自由記 述データから得られた記述を参考にして, 項目の改良を行うことが重要である。

第3に, 本論で用いた方略には, 授業活動レベルの内発的動機づけと授業レベ ルの内発的動機づけを高める効果があったものの, その効果は特性レベルの内発 的動機づけまでは波及しなかった。授業に密着した内発的動機づけを高めることに 成功したという点では, この方略の効果が否定されたわけではない。ただ, 先行研究 （Hiromori， 2006, 廣森・田中，2006, 田中・廣森，2007）では, 介入によって特性レベ ルの内発的動機づけ高られるという結果を示している。今後は特性レベルの内発的 動機づけにも効果が波及するように, 本調査で用いた方略の設計をアレンジしていく 必要があろう。

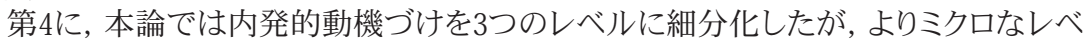
ルの動機づけほど, コンテクストや状況に依存する割合が大きくなる。これは, 動機 づけを捉える視点を細分化することが諸刃の剣であることを示している。分析の単位 を細かくすればするほど, 教室での学習者の動機づけ状態をより詳細に把握できる。 その一方で, 状況依存性が高まってしまい, 結果の一般化が求めにくくなる。本論で は大学生の内発的動機づけを高めるという目的, 特に, 方略の効果を細分化して捉 えるという視点から, あえてミクロなレベルの動機づけにも焦点をあてた。このような メリット, ディメリットの選択は, 研究目的と相関的に決定されるものであろう。今後 は, 研究成果を積夕重ねることで, 一般化可能性を高める必要がある。

第5に, 本論の質的研究の結果から, 新たな動機づけを高める要因として, 実用性 の付与が創出された。これらは仮説の段階であるので, 今後の量的研究による裏づ け, 理論的妥当性のさらなる検証が必要である。実用性が内発的動機づけ, あるい は内発的動機づけに近い形の動機づけをどの程度高めたかどうかは, 質的研究から は十分に把握できない。質的研究は要因間のダイナミックな関係性を想定できるメリ ットがある一方, 要因間の関連性の強さを明示的に示すことが困難であるというディ メリットがある。実用性と内発的動機づけの関連性は, 今後の量的研究による裏づけ が必要であろう。またこれらの要因は, 本論の調査で用いられた動機づけを高める方 略に独自の要因か, それとも, それ以外の動機づけが高まる過程でも, 動機づけを高 める要因として機能し得るか, という点も今後の検討課題である。

第6点目に, 本論では動機づけの変動のみで, 学力の変動を扱っていない。今後は 学力の要因も絡めた議論が必要であろう。また, 本論で扱われた授業活動レベルの 内発的動機づけはリスニングとスピーキングのタであった。しかし, 授業活動には, 書 くこと, 読むことなど, 多様な活動があるため, 今後は授業活動レベルの内発的動機 づけの枠を広げることも必要であろう。

第7点目に, 本論は学習者に介入を行う前後で動機づけの変動を捉えるデザイン である。本来ならば, 実験群に対して統制群を置くことで, 介入の効果をより明示的 に示すべきである。しかし, 本調査は実際の授業の中で動機づけを高めることに主眼 を置いているため, 統制群を置くことは困難である。このような限界点を力バーするた めに, 本調査では質的デー夕も収集し, 可能な限り介入の効果を明示的に捉えようと した。今後は何らかの形で統制群を設定し, より詳しい分析を行う必要があろう。 


\section{注釈}

1 以下, 本論では単に「方略」と記述した場合も, 動機づけを高める方略を意味 する。

2 近年は, Guilloteaux and Dörnyei (2008)のように, 特定の方略を事前に設定せ ずに, The Motivation Orientation of Language Teaching (MOLT)を用いた授業 観察から得られた教員の動機づけを高める方略と学習者の動機づけの関連を 扱う研究も見られる。

3 質問項目の詳細はAppendix Cを参照。

$4 \alpha$ は1時点から3時点の3つの值を記述している。表記は1時点, 2時点, 3時点で ある。

5 KJ法は川喜田(1967)から川喜田(1986)の19年間にかなりの発展を見せてい る。川喜田(1986)のKJ法では, 例えば,「紙切れ作り」が「ラベル作り」に変更さ れるなどの用語の変更, 島どりの追加や関係線のバリエーションの増加, また A型図解によるシンボルマークの導入によるビジュアル性の向上などが見られ る。よってKJ法は川喜田(1967)版と川喜田(1986)版に区別した方がよいと思 われる。また, 累積KJ法に関しても, 川喜田(1967) と3年後の川喜田(1970)で

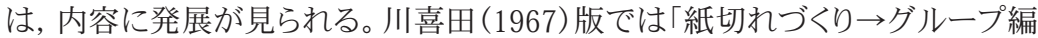
成 $\rightarrow \mathrm{A}$ 型図解 $\rightarrow \mathrm{B}$ 型文章化までを1サイクルとすると, そのサイクルを累積的に いくつも重ねる方法である」(pp. 111-112) と定義している一方, 川喜田(1970) ではW解決に沿った (6ラウンドの) 累積KJ法を扱っている。W解決に沿った(6ラ ウンドの) 累積KJ法は川喜田(1986)版に継承されており, 川喜田(1967)版の累 積KJ法とは異なることから, 川喜田(1986)版に含めるのがよいと思われる。本 論で用いたKJ法は初期の川喜田（1967）版に基づいており, 用語の用い方, 分 析の手順, 図解の方法, 累積KJ法の方法は, すべて川喜田(1967)版に準拠し ている。

6 各項目の平均值を尺度の得点と夕なしている。

7 このような傾向は, 本論で用いた方略において一般的現れる傾向であるのか, それとも, 今回の調査協力者は有能性の欲求をそれほど大きく満たすことがで きなかったことに起因するのかは, さらなる調査が必要であろう。

\section{引用文献}

Crookes, G., \& Schmidt, R. (1991). Motivation: Reopening the research agenda. Language Learning, 41, 469-512.

Deci, E. L., \& Ryan, R. M. (2002). Handbook of self-determination research. Rochester, NY: University of Rochester Press.

Dörnyei, Z. (1990). Conceptualizing motivation in foreign language learning. Language Learning, 40, 46-78.

Dörnyei, Z. (1994). Motivation and motivating in the foreign language classroom. Modern Language Journal, 78, 273-284.

Dörnyei, Z. (1998). Motivation in second and foreign language learning. Language Teaching, 31, 117-135.

Dörnyei, Z. (2001). Motivational strategies in the language classroom. Cambridge: Cambridge University Press. 
Ehrman, M., \& Oxford, R. (1989). Effects of sex differences, career choice, and psychological type on adult language learning strategies. Modern Language Journal, 72, 1-13.

Gardner, R. C., Masgoret, A. M., Tennant, J., \& Mihic, L. (2004). Integrative motivation: Changes during a year-long intermediate-level language course. Language Learning, 54, 1-34.

Gardner, R. C., \& Tremblay, P. F. (1998). Specificity of affective variables and trait/ state conceptualization of motivation in second language acquisition. In R. K. Agnihotri, A. L. Khanna, \& I. Sachdev (Eds.), Social psychological perspectives on second language learning (pp. 31-52). New Delhi: Saga Publications.

Glaser, B. G., \& Strauss, A. L. (1967). The discovery of grounded theory: Strategies for qualitative research. Chicago: Aldine Publishing Company.

Guilloteaux, M. J., \& Dörnyei, Z. (2008). Motivating language learners: A classroomoriented investigation of the effects of motivational strategies on student motivation. TESOL Quarterly, 42, 55-77.

Hiromori, T. (2006). The effects of educational intervention on L2 learners' motivational development. JACET Bulletin, 43, 1-14.

廣森友人・田中博晃. (2006).「英語学習における動機づけを高める授業実践: 自己決定理論の 視点から」. Language Education and Technology, 43, 111-126.

川喜田二郎. (1967).『発想法 - 創造性開発のために』. 東京: 中央公論社.

川喜田二郎. (1970).『続·発想法』.東京: 中央公論社.

川喜田二郎. (1986).『KJ法一混沌をして語らしめる』. 東京: 中央公論社.

菊地一彦・中山勘次郎. (2006).「外国映画のリスニングが中学生の学習意欲に及ぼす影響」『 教育心理学研究』, 2, 254-264.

Kimura, Y., Nakata, Y., \& Okumura, T. (2001). Language learning motivation of EFL learners in Japan: A cross-sectional analysis of various learning milieus. JALT Journal, 23, 47-68.

三浦省五. (1983).『英語の学習意欲』. 東京: 大修館書店.

田中博晃. (2005a).「「英語授業への動機づけ」の概念化: 高校生を対象にした検討」.『中国地区 英語教育学会研究紀要』, 36, 41-48.

田中博晃. (2005b).「どのようにすれば学習者の動機づけは高められるのか?: 学習者の動機づ けを促進する方略の効果検証」. JALT Journal, 7, 163-176.

田中博晃. (2006).「「英語授業への動機づけ」と英語学習一般への動機づけ:因果関係の検討」. 『中国地区英語教育学会研究紀要』, 36, 41-48.

田中博晃・廣森友人. (2007).「英語学習者の内発的動機づけを高める教育実践的介入とその効 果の検証」. JALT Journal, 29, 59-80.

Vallerand, R. J., \& Ratelle, C. F. (2002). Intrinsic and extrinsic motivation: A hierarchical model. In E. L. Deci, \& R. M. Ryan (Eds.), Handbook of self-determination research (pp. 37-63). Rochester, NY: University of Rochester Press.

Vallerand, R. J., Pelletier, L. G., Blais, M. R., Briere, N. M., Senecal, C., \& Vallieres, E. F. (1992). The academic motivation scale: A measure of intrinsic, extrinsic, amotivation in education. Educational and Psychological Measurement, 52, 1003-1017.

Vandergrift, L. (2005). Relations among motivation orientation, megacognitive awareness and proficiency in L2 listening. Applied Linguistics, 26, 70-89. 
Williams, M., \& Burden, R. (1997). Psychology for language teachers: A social constructivist approach. Cambridge: Cambridge University Press.

Appendix A. リスニング活動における学習者の記述の分類結果
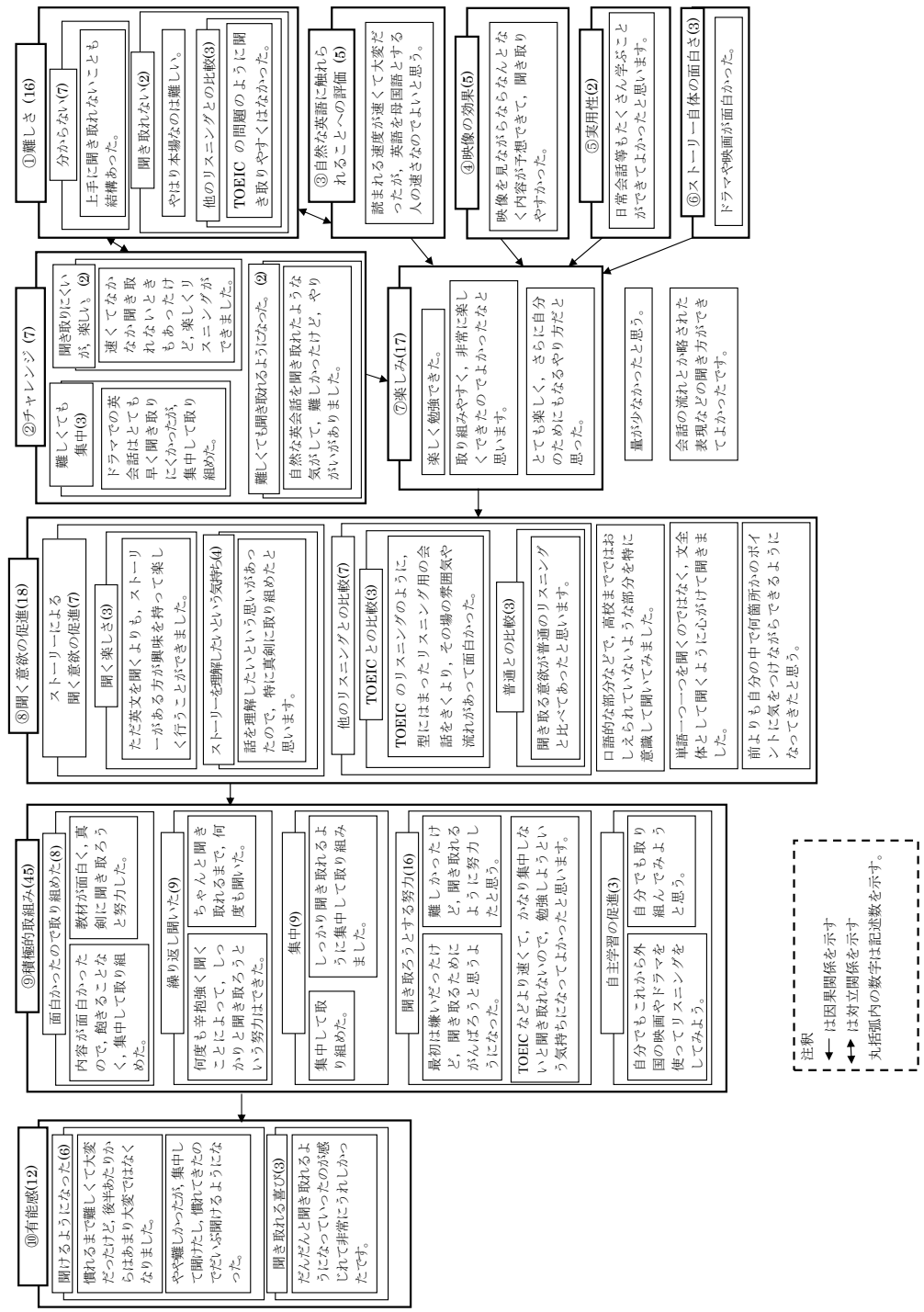
Appendix B. スピーキング活動における学習者の記述の分類結果
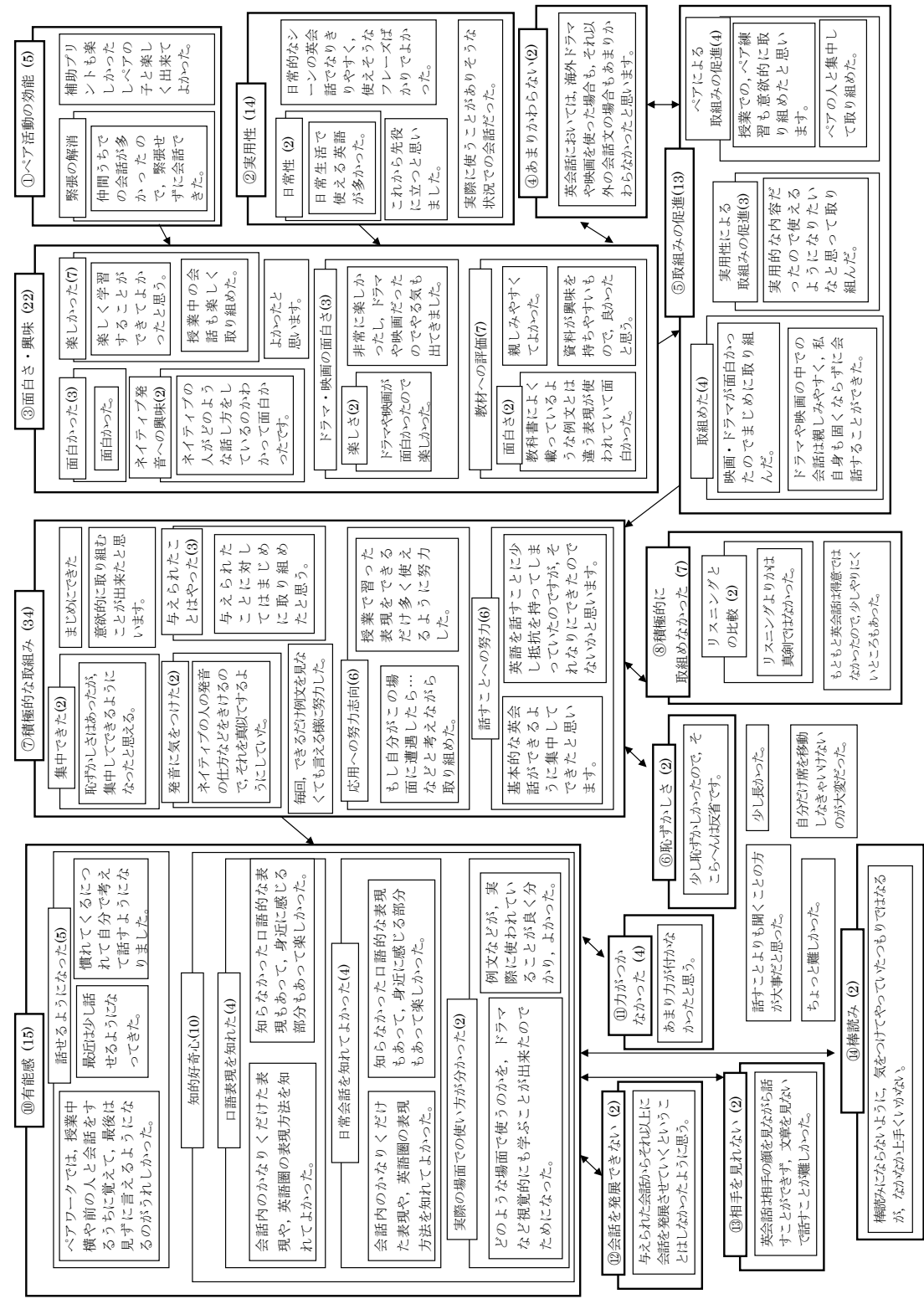


\section{Appendix C. 調査で用いられた質問項目}

第 1 部

【特性としての動機づけ】

英語を勉強している時に，「あっそうか」や「なるほど」と思うような発見がある。

英語を勉強することで，初めて気づくことがあると嬉しい。

英語圈の人々や, 彼らの生活様式について知るのは楽しい。

英語ができるようになると，今までとは違う自分の新しい一面を見ることができる。

英語を勉強し続けていると，今まで聞き取れなかった単語や言葉がわかるようになるのが嬉しい。

【リスニング活動への動機づけ】

英語の授業では，リスニングの時は集中できている。

英語の授業では，リスニングに熱心に取り組んでいる。

英語の授業では，英語を聞き取ろうとがんばっている。

【スピーキング活動への動機づけ】

英語の授業では，スピーキングに集中できている。

英語の授業では，スピーキングに熱心に取り組んでいる。

英語の授業では，英語を話そうとがんばっている。

【英語授業への動機づけ】

英語の授業は，おもしろいと思う。

英語の授業は，楽しくて時間が過ぎるのが早いと感じる。

英語の授業を，楽しみにしている。

英語の授業では，好奇心が刺激されると思う。

第 2 部

【自律性】

英語の授業では, 教材・授業の進め方・学習内容に関して, 私たちにある程度の選択の自由が, 与 えられていると思う。

英語の授業では，先生は私たちの授業に関する意見を尊重してくれていると思う。

英語の授業では，授業の進め方の希望などを，先生に伝える機会が与えられていると思う。

英語の授業では，プレッシャーを感じずに勉強をすることができると思う。

【有能性】

英語の授業では,「できた」という達成感が得られると思う。

英語の授業では，先生やクラスメイトから「よくできた」と誉められるなど，良い評価をしてもら えると思う。

英語の授業では,「よくがんばった」という満足感が得られると思う。

英語の授業では，「分かった」という充実感が得られることがあると思う。

\section{【関係性】}

英語の授業では，同じ教室の仲間と仲良くやっていると思う。

英語の授業でのグループ活動・ペアワークでは, 協力し合う雰囲気があると思う。

英語の授業では，和気あいあいとした雾囲気があると思う。

英語の授業では, 同じ教室の仲間同士で学びあう雾囲気があると思う。 